CHAPTER FOUR

\title{
A QUECHUAN MIRATIVE?
}

\author{
Willem F.H. Adelaar
}

\section{INTRODUCTION $^{1}$}

A number of Quechuan language varieties spoken in the Central Peruvian Andes, more specifically, in the northwestern part of the department of Junín and adjacent areas of the departments of Lima and Pasco, feature a special category of verb forms that has the exclusive function of denoting the surprising nature or unexpectedness of an ongoing event or situation. From a perspective of grammatical organization, this category functions as a 'tense' and constitutes, together with a number of other tense categories, the unmarked or indicative mood in the verbal conjugation of the language varieties in question. Thus, it stands in a paradigmatic relationship with other categories that mainly convey temporal (and occasionally aspectual) functions, such as past, past habitual, present and future. In a grammatical study of the varieties spoken in the province of Tarma in the department of Junín (henceforth Tarma Quechua), ${ }^{2}$ this 'tense' denoting unexpectedness has been defined, under the denomination of sudden discovery tense, as a category that "refers to events that have been going on unnoticed and which are suddenly discovered by the speaker or by another person playing a central role in the narrative" (Adelaar 1977: 96). A straightforward English translation for this Quechuan tense category could be introduced by the phrase "it turned out that...". Its semantic characteristics are closely akin to those of the category of mirative as defined in recent typological literature (DeLancey 1997, 2001; Aikhenvald 2004: 195-215).

A noteworthy feature of the mirative in Tarma Quechua is that it is mainly used in objective, non-emotional statements. Although it refers to

\footnotetext{
1 I am grateful to Alexandra Aikhenvald, Kees Hengeveld, Hella Olbertz, Anne Storch and an anonymous reviewer for their valuable comments.

2 These varieties belong to the southern representatives of Quechua I, one of the main subdivisions of the Quechuan language family along with Quechua II. The denominations Quechua I and Quechua II were taken from Torero's (1964) classification.
} 
situations that may have been surprising to the speaker at the moment he/she became aware of them, its main function lies in the impact it has on the audience. Tarma Quechua miratives are most frequently found in narratives. However, the boundary between narrative and conversational accounts in Quechuan languages is not a strict one, and miratives can also be found in interactive contexts with the same connotation of objectivity.

In many other Quechuan languages, as well as in Aymara (Matt Coler pers. comm.), the mirative reading emerges as a secondary usage of one of the indicative tenses (Narrative past, Remote or Mythical past, Perfect, etc.) that also cover other, more familiar interpretations. A peculiarity of the Quechuan language varieties spoken in the Central Peruvian area delineated above is that their tense system includes a category of forms that has no other function than to convey mirative meaning.

One of the questions that will be addressed in this article is whether or not the provisional semantic definition of the Tarma Quechua Mirative is compatible with the notion of mirativity as generally used in the linguistic literature. The uniquely distinct character of the mirative category in Tarma Quechua will be made visible by contrasting it with other subsystems of Tarma Quechua morphosyntax, such as aspect, negation and evidentiality. It will be shown that the Tarma Quechua Mirative does not behave like an evidential category, that it functions independently of aspect (though not of tense!), and that it is incompatible with negation.

First, however, the formal characteristics of the Tarma Quechua Mirative and its possible historical background are presented in a comparative perspective.

\section{FORM AND ORIGIN}

The mirative verbal 'tense' in Tarma Quechua is marked by means of an affix ${ }^{3}$ Like other tense-marking affixes, it appears in combination with cross-referential person-marking affixes referring to an agent (A/S) and, when relevant, also to a patient $(\mathrm{O} / \mathrm{IO})$, which must be a human or humanized participant in the speech act. Forms denoting agent/subject alone or 'direct' relations between participants and/or non-participants that are in compliance with a person hierarchy $1>2>3$ take simple crossreferential endings, as shown in Table 4.1:

\footnotetext{
3 As other Quechuan languages, Tarma Quechua is predominantly suffixing. All affixes are suffixes.
} 
Table 4.1. Direct cross-referential endings of the Tarma Quechua Mirative

\begin{tabular}{ll}
\hline $1 \mathrm{~A} / \mathrm{S}[>3 \mathrm{O} / \mathrm{IO}]$ & - na-:* \\
$2 \mathrm{~A} / \mathrm{S}[>3 \mathrm{O} / \mathrm{IO}]$ & - na-y[ki] $]^{* *}$ \\
$1 \mathrm{~A} / \mathrm{S}>2 \mathrm{O} / \mathrm{IO}$ & - na-q \\
$1+2 \mathrm{~A} / \mathrm{S}[>3 \mathrm{O} / \mathrm{IO}]$ & - na-nči[k]*** \\
$3 \mathrm{~A} / \mathrm{S}[>3 \mathrm{O} / \mathrm{IO}]$ & -naq \\
\hline
\end{tabular}

* The vowel length that indicates $1 \mathrm{~A} / \mathrm{S}$ may have originated from a segmental affix $-y$ (Adelaar 1984).

** The element $-k i$ (dialectally $-g i$ ) of the $-y[k i]$ ending is not pronounced, except word-finally. If it is omitted in word-final position as well, stress (normally penultimate) remains located on the syllable that precedes the omitted element.

*** The element $-k$ in $-n c ̌ i[k]$ is optional in some dialectal varieties but absent in others.

By contrast, the counter-hierarchical ('inverse') relations are expressed by means of combined cross-referential endings, as shown in Table 4.2:

Table 4.2. Inverse cross-referential endings of the Tarma Quechua Mirative

\begin{tabular}{|c|c|}
\hline $2 \mathrm{~A} / \mathrm{S}>1 \mathrm{O} / \mathrm{IO}$ & -ma:-na-y[ki] ${ }^{* *}$ \\
\hline $3 \mathrm{~A} / \mathrm{S}>1 \mathrm{O} / \mathrm{IO}$ & -ma:-naq \\
\hline $3 \mathrm{~A} / \mathrm{S}>1+2 \mathrm{O} / \mathrm{IO}$ & -ma:-na-nči $[\mathrm{k}]^{* * *}$ \\
\hline $3 \mathrm{~A} / \mathrm{S}>2 \mathrm{O} / \mathrm{IO}$ & -šu-na-y[ki] $]^{* *}$ \\
\hline
\end{tabular}

The affix -naq ' 3 A/S Mirative' deserves special attention because it contains an element $-q$, which is not otherwise found as a 3 A/S marker. Probably, the original Mirative ending can be reconstructed as *naq, a form which is still found in some phonologically conservative Central Peruvian varieties (Huanca Quechua, Pacaraos Quechua). As it seems, *-ñaq was originally used only as a $3 \mathrm{~A} / \mathrm{S}$ form, but it could be combined in a compound paradigm with inflected forms of the auxiliary verb $\mathrm{ka}$ - 'to be' in order to denote all other attested cross-referential forms. This situation is still found in Pacaraos Quechua (province of Huaral, department of Lima). Apparently, the Tarma Quechua Mirative paradigm, which does not involve any overt forms of the verb 'to be', consists of contracted forms based on such a compound paradigm. ${ }^{4}$

\footnotetext{
4 Black et al. (1990: 264), who use the label 'narrative past' in their study of the Quechua of Northern Junín and Southeastern Pasco, provide an unambiguous example of -naq with
} 
The reconstructed form * $-\tilde{n} a q$ can tentatively be derived from a combination of * $\tilde{a}$ 'already' with the agentive nominalizing affix $-q$. This element $\tilde{n} a$ operates in many Quechuan varieties as an affix or a lexically free adverb. ${ }^{5}$ Nominalized verbs containing the affix $-q$ are used in most Quechuan languages with forms of the auxiliary verb $k a$ - 'to be' in a compound tense paradigm that denotes Habitual past. Consequently, *naq may be analyzed diachronically as a combination of Habitual past with * $\tilde{n} a$, except that the latter appears in an anomalous location before the nominalizing affix.

In the Huanca varieties, which are spoken in the Andean part of the department of Junín south-east of Tarma Quechua, reflexes of either *-naq or *-ña are found according to localities. ${ }^{6}$ Although contracted forms are preferred over analytic constructions with $k a$-, both options have been attested. Descriptive studies of the Huanca varieties (Cerrón-Palomino 1976, Wroughton 1996) apply the label 'Narrative past' (Spanish pasado narrativo) to the forms at issue, suggesting that they are used, at least in some of these varieties, both as a narrative past and as a means to convey mirative meaning. A collection of texts reproduced in Wroughton (1990: 81-150) contains evidence that this is definitely the case for varieties spoken in the area of Jauja.

Forms in -naq (or its reflex -na:) are found throughout the remaining (northern) varieties of the Quechua I branch. These forms convey different types of meaning, and a semantic value akin to mirative is usually one of them (cf. Howard 1988: 130-131, Weber 1989: 114-115, Hintz 2011: 84). ${ }^{7}$ In some of the northern Quechua I dialects spoken in the department of Ancash -naq ( -na:) is combinable with other tense markers, which puts in doubt its status as a component of the tense system. Parker (1976:111-2) treats it as a modal rather than a temporal element, although mirative meaning is clearly present.

mirative meaning as defined in this article, but none that could be qualified as an instance of narrative past in particular.

5 In Ayacucho Quechua (a Quechua II variety), the element $\tilde{n} a$ occurs both as an affix and as an adverb with identical meanings. The adverb $\tilde{n} a$ has to be accompanied by at least one other constituent that contains the affix - $\tilde{n} a$ (unless the adverb constitutes an utterance by itself). Conversely, the affix need not be reinforced by the adverb.

6 Originally a post-velar stop, * $q$ has undergone different types of change in the Huanca dialects.

7 In his study of South Conchucos Quechua, Hintz (2011: 137-42) also assigns mirative meaning to a number of aspect suffixes thus distinguishing several 'miratives' with different functions and use. 
In Quechua II, the mirative meaning associated with Quechua I *-naq or *naq is usually expressed by means of the non-agentive participle and nominalizer in *-shqa, or one of its reflexes, in combination with the auxiliary verb $k a$ - 'to be'. Again, both contracted and non-contracted paradigms occur. In Quechua II, the *-shqa paradigm regularly combines mirative meaning with other more frequent meanings. ${ }^{8}$ Attested functions of the *-shqa paradigm in Quechuan languages are Narrative past (Quechua II: Ayacucho Quechua, Cuzco Quechua), Perfect or Experiential past (Pacaraos Quechua; cf. Adelaar 1986), ${ }^{9}$ and Recent past (Quechua I: South Conchucos Quechua; cf. Hintz 2007: 16-18)..$^{10}$ This situation suggests that in most Quechuan languages the Mirative is based on a semantic extension of tense-like verb forms, such as Perfect, Habitual or Narrative past, a development which resembles the rise of evidential strategies from perfect, resultative and past tenses in languages of the eastern Mediterranean basin and other parts of the world (cf. Aikhenvald 2004: 112-116).

\section{Meaning and Use}

The Mirative tense in Tarma Quechua and adjacent varieties indicates a fact or occurrence that is objectively surprising. Although a speaker may express surprise at an event of which (s)he had not been previously aware, (s)he may also reveal information already familiar to him/her but still likely to surprise an audience. The Tarma Quechua Mirative often refers to information that is withheld from the addressee until the speaker sees fit to reveal it, a frequent strategy in narratives of which the unexpected outcome is reserved for the end. By consequence, the speaker him/herself need not be under the impact of surprise any longer when using the Mirative. The speaker shows no particular excitement, and there is no exclamation of surprise. Essential is the fact that in a previous time span an event has occurred or a state has been in place, unnoticed by the speaker or any other person relevant to the communicative context. Characteristically,

8 The establishment of criteria to distinguish between mirative and non-mirative use of tense categories in the different Quechuan languages is a complex task that lies beyond the scope of this article.

9 The classificatory status of Pacaraos Quechua is undecided. From a morphological point of view it is close to Quechua I, but it may possibly occupy a position outside the Quechua I / II dichotomy.

10 Tarma Quechua has no compound tense based on *-shqa. Its reflex -sha has mainly an attributive function and cannot be combined with cross-referential affixes, except in one very specific construction. 
actions performed during one's sleep or in a state of unconsciousness are expressed in the Mirative (cf. Cerrón-Palomino 1987: 273). The Mirative can also be used in recounting dreams (see Floyd 1999: 64-65, cited in Aikhenvald 2004: 345, for an example from Huanca Quechua).

In Tarma Quechua, as in the neighbouring Huanca varieties (Floyd 1999, cf. Aikhenvald 2004: 203), the Mirative can also indicate an expected surprise, the uncertain outcome of an experiment still to be undertaken or an impending revelation (see Section 8 below). Such exceptional usage clearly shows that the classification of the Mirative as a tense is related to grammatical organisation, rather than to genuine temporal semantics.

According to DeLancey (2001), "the term mirativity refers to the linguistic marking of an utterance as conveying information which is new or unexpected to the speaker." In Aikhenvald (2004: 209) mirativity is defined as "a grammatical category whose primary meaning is speaker's unprepared mind, unexpected new information, and concomitant surprise." As we can see, the definitions by DeLancey's and Aikhenvald broadly match the semantic description of the Tarma Quechua Mirative, except that the requirement of newness or unexpectedness does not necessarily apply to the speaker's state of knowledge. The Tarma Quechua Mirative stands out for its non-emotional, matter-of-fact connotations. It remains a question if the Quechuan Mirative must be placed outside the general concept of Mirative, or if the current definitions and semantic and functional characterizations of Mirative in grammatical descriptions of other relevant languages should be reformulated. ${ }^{11}$

Quechuan languages are known for the existence of sharp semantic and functional divisions between the different grammatical subsystems and the high level of organization of the latter. ${ }^{12}$ Apart from its seemingly arbitrary classification as a tense, the Tarma Quechua Mirative is no exception to this rule. In the following sections we will see how the Mirative is incorporated within the tense system (4) and how it can be combined with aspect markers (5) and with evidential markers (6). A constraint on the occurrence of the Mirative in negative sentences is presented in section (7). In section (8) we discuss the use of the Mirative in

11 In a recent paper, Hengeveld and Olbertz (forthcoming) propose a new definition for the mirative based on the newsworthiness or unexpectedness of a proposition. Such definition appears to fit the Quechuan category under discussion quite felicitously.

12 Exceptions are found in the derivational morphology internal to the verb form, in particular in Quechua I, and in the fluid transition between the categories transitive and intransitive in the Andean languages in general. 
Table 4.3. Tense in Tarma Quechua

\begin{tabular}{|c|c|c|}
\hline Present/unmarked & wata- $\underline{n}$ & 'he/she ties (it)' \\
\hline Future & wata-nqa & 'he/she will tie (it)' \\
\hline Past & wata-ra & 'he/she tied (it)' \\
\hline Mirative & wata-naq & 'it turns out that he/she had tied (it)' \\
\hline Habitual/narrative past & wata-q & $\begin{array}{l}\text { 'he/she used to tie (it)'. 'he/she } \\
\text { would tie (it)'13 }\end{array}$ \\
\hline
\end{tabular}

interrogative utterances with special attention for the experimental Mirative (see above), which from a formal point of view is also an interrogative utterance. The incompatibility of the Mirative with exclamations is illustrated in section (9) with examples from Highland Ecuadorean Quichua collected by Olbertz (2009).

\section{Mirative and Tense}

In Table 4.3, the relation between Mirative and tense in Tarma Quechua is illustrated with an inventory of the $3 \mathrm{~A} / \mathrm{S}$ forms of the tenses of the (unmarked) indicative mood. It clearly shows the paradigmatic relation between Mirative and the other indicative tenses, even though the semantic contribution of Mirative can be characterized as modal, rather than temporal.

\section{Mirative AND Aspect}

Tarma Quechua has a rather transparent verbal aspect system consisting of three mutually exclusive categories: Perfective, Progressive and Customary. Although one of the tenses, the Habitual, may have an aspectual overtone, tense and aspect are grammatically separate. There is no fusion of tense and aspect markers in portmanteau morphemes. The use of aspect markers is subject to some grammatical constraints and considerations of register (cf. Adelaar 1988, see also $§ 7$ ). Many speakers use aspect markers in all contexts in which they are allowed. Otherwise, verbs that are not marked for aspect refer to general truths. As the following examples show, the Mirative is freely combinable with all three aspect categories: Progressive aspect in (1), Customary in (2), and Perfective in (3).

13 The habitual/narrative past is a compound tense, which contains forms of the verb 'to be' in all orms other than $3 \mathrm{~A} / \mathrm{S}$ and $3 \mathrm{~A} / \mathrm{S}>1 \mathrm{O} / \mathrm{IO}$. 
(1) turumanya inti-ta-m muyu-ra-ya:-naq rainbow sun-ACC-CERT turn-CONT-PROG-3A/s.MIR a rainbow was surrounding the sun

(2) chawra-qa cha:-qa ka-ku-na[q] ${ }^{14}$ alqu then-TOP that-TOP be-CUST-3A/s.MIR dog so it turned out that he was a dog [not a human being as he had appeared to be]

$(\text { San Pedro de Cajas })^{15}$

(3) yarga-ra-:ri-na-:

masya:du karu-ta-m go_upward-PERV-PL-MIR-1A/s too_much far-ACC-CERT we realised that we had climbed too far

\section{Mirative and Evidentials}

Tarma Quechua has a transparent system of evidentials consisting of three mutually exclusive categories: Certainty, Reported and Conjectural. The 'Certainty' evidential implies a firm conviction on the side of the speaker. It does not always mean that the speaker has witnessed the communicated state or event in person, but the utterance contains information that (s)he can vouch for. The 'Reported' refers to facts communicated by rumour or hearsay. Its use implies that the speaker feels no personal responsibility for the truth value of what (s)he is communicating. Understandably, the Reported evidential is frequently used in narratives. If the source of the information is a known person who can be identified by name, a quotation construction will be used, rather than a Reported evidential. The 'Conjectural' evidential is mainly used to indicate a guess of the speaker. In that case there are no firm indications that the utterance is actually true, but it refers to a situation or event that can provide a plausible explanation for a state-of-things familiar to the speech act participants.

The use of evidentiality markers is not strictly obligatory, but most speakers use them in all contexts in which they are allowed. Evidentiality is marked at the sentence level, usually (but not always) after the first constituent of the sentence. As can be deduced from the examples (1) and (3), the Mirative is freely combinable with the evidential that marks

\footnotetext{
14 In some dialectal varieties of Tarma Quechua the final - $q$ of the ending -naq can be silent in word-final position.

15 The variety of San Pedro de Cajas differs from the variety spoken in the surroundings of Tarma in a number of phonological aspects. Its morphosyntax, however, is nearly identical. We only indicate the dialect provenance of data that are not from the immediate neighbourhood of Tarma itself.
} 
Certainty. A further example of this combination from the related dialect of Pacaraos, which behaves in the same way in this respect, is given below under (4). It shows that the presence of the evidential marker of Certainty does not imply that the speaker has witnessed the event when Mirative is involved.

(4) altu-ĉaw ka-yka-nqa-y-kama-m

highlands-LOC be-PROG-NOMZ-1A/s-DLMT-CERT

intrega-rqa-ma:-ñaq mamá-y

give_away-PERV-10/IO-3A/s.MIR mother-1POSS

while I was staying in the highlands, my mother had given me away [in marriage]

Example (5) shows that the Mirative is also combinable with the Reported evidential. The Reported speech marker is used here because the sentence is part of a narrative which in its totality is derived from hearsay.

(5) ima-sh ga-naq, rachak-shi kinra-n kinra-n what-REP be-3A/s.MIR toad-REP side-3Poss side-3Poss cura-naka-ra-:ri-na[q] caski-yubay-si place-RECIP-PERV-PL-3A/S.MIR relay_runner-COMPAR-ADD what had actually happened? The toads had posted each other on different spots along the track as in a relay-race

(Vienrich 1961: 36)

The Tarma Quechua Mirative has not been attested in combination with the Conjectural evidential marker. This should not come as a surprise because the Conjectural always refers to situations that are not necessarily true, whereas the Mirative refers to facts or events that are not in doubt.

\section{Mirative and Negation}

The Tarma Quechua Mirative does not occur in negative sentences. This rather unexpected conclusion can be drawn from two considerations. Firstly, no instances of Mirative in negative sentences are attested in our data. Secondly, main verbs in negative sentences that convey an element of sudden awareness or unexpectedness are not marked for Mirative, but for some other tense. The following examples illustrate this. In (6), the main verb of the sentence is in the plain Past tense, not in the Mirative. In (7), the Habitual is used in its Narrative past interpretation in an utterance with a clear mirative overtone. 
(6) man-ta qam ka-ra-y-chu chay o:ra-qa, nuqa not-CONTRA you be-PAST-2A/s-NEg that time-TOP, I/we rikaĉaku-rka-ya-ra-q-ta look_out-PL-PROG-PAST-1A/s>2O/IO-CONTRA you were not there then [although we had agreed to meet there]. We were looking out for you

(San Pedro de Cajas)

(7) chay-bita ali yarba-rgu-tbi-n-qa, mana-m ni that-ABL well think-DIR-SUBORD.DS-3A/s-TOP not-CERT not_even imay ca:-mu-na-n-si ga-q-chu when arrive-vENT-FUT.NOMZ-3A/s-ADD be-3A/s.HAB-NEG then, when he thought about it properly, [he realized] there was no way to ever come down again

The incompatibility of Mirative and negation remains unexplained. However, it should be observed that Tarma Quechua exhibits a similar constraint on the co-occurrence of aspect and negation. Aspect markers are banned from the main verb in a negative sentence, as has been ascertained through tests in which speakers were asked to negate verbs marked for aspect. In those cases, aspect markers were systematically removed and all aspect distinctions neutralized. As it seems, the answer must be sought in the overall way negation is conceived by speakers of Tarma Quechua. Negation apparently makes both Mirative marking and aspect marking irrelevant.

It should be observed that the incompatibility of Mirative and negation is by no means a general feature of the Quechuan languages. In Pacaraos Quechua Mirative and negation are combinable (8).

(8) peru say mana-sh arros-ta mika-ri-ñaq-su but that not-rep rice-ace eat-pl-3a/smir-neg but, reportedly, it turned out that they did not eat rice ${ }^{16}$

\section{Mirative and Interrogative: The Experimental Mirative}

As we have seen in example (5), the Mirative is occasionally found in interrogative expressions. In a majority of cases such interrogative expressions occur as embedded questions in an utterance in which the addressee is encouraged by the speaker to perform an experiment of which the out-

\footnotetext{
16 Possible cases of mirative use in negative sentences have been attested in Cuzco Quechua as well (Cusihuamán 1976: 171; Xiomara Sánchez, pers. comm.).
} 
come, for as yet unknown, is expressed in the Mirative form in combination with both an interrogative element and the Reported speech evidential. The interrogative element can either be an interrogative pronoun (wH-expression) (9), or the affix -chu, which marks a polar question (10). Note the highly conventional nature of this construction with its three obligatory components (Mirative, Reported speech marker and interrogative element). In it, the Mirative does not refer to an event in the past or present, and the Reported speech evidential does not refer to information from hearsay, but rather to knowledge to be obtained by an action that still has to be performed.

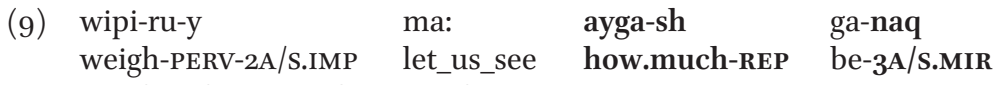
weigh it, let us see how much it is!

(10) ma: tupa-yu-y kuyu-ri-naq-chu-sh let_us_see bump_into-DIR-2A/S.IMP move-INCEP-3A/S.MIR-INTER-REP why do not you give it a push to see if it moves or not!

As we have noted before, this highly specific construction has a wider distribution than just Tarma Quechua. It has been attested as a so-called 'challenge construction' by Floyd (1999) for the neighbouring Huanca dialects (cited in Aikhenvald 2004: 203). The utterance in (11) does not contain a hortative verb form, as the previous examples do, and the Mirative is not part of an embedded question. However, the semantic effect is similar.
(11) ma: mayan-man-shi chay illay-kuna-:-ta u-ña let_us_see who-ALL-REP that money-PL-DEF-ACC give-3A/s.MIR let us find out who he gave the money to

(Floyd 1999: 150)

More neutral examples of the use of Mirative in interrogative sentences, not involving any challenge or uncertain outcome, can be found in (5) and in the following example from Pacaraos Quechua (12). ${ }^{17}$
(12) wikuña aská-s ka-rqu-ñaq o icha-lá- vicuña many-INTER be-PERV-3A/s.MIR or few-DIM-INTER did you find that there were many vicuñas or just a few?

17 In Pacaraos Quechua polar questions are indicated with an affix -su, which is usually reduced to $-s$ after a vowel when the affix occupies the word-final position. In that case stress is maintained on the preceding vowel. 


\section{Mirative AND EXClamation}

As we have noted before, the Mirative in Tarma Quechua does not imply any emotional expression. Characteristically, mirative statements are objective in character. In Tarma Quechua, as in most other Quechuan languages, exclamations are easily recognized by the presence of specific clitic elements or by a shift of stress to the word-final syllable (or a combination of both strategies). None of the Miratives that are part of our data have been found in such specific exclamatory contexts.

For examples that illustrate this state-of-affairs we may refer to a study by Olbertz (2009) on the use of Miratives in Highland Ecuador. In Ecuadorean Highland Quichua, statements in the Mirative form are objective and non-emotional (13), whereas exclamatory utterances of surprise (14) do not take the Mirative, but the unmarked Present tense form.

(13) kipi llashak-mi ka-shka bundle heavy-CERT be-3A/s.MIR the bundle is heavy indeed

(Olbertz 2009: 70)

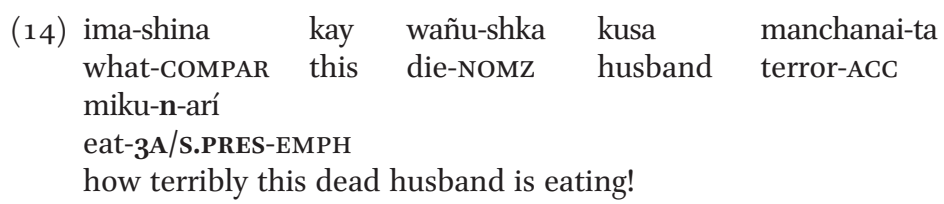

(Olbertz 2009: 73)

The objective character of the Quechuan Mirative is also illustrated in example (15) from Pacaraos Quechua, which is parallel in meaning to (13).
(15) aya-ku-ñaq miku-na-yki
spicy-CUST-3A/s.MIR eat-NOMZ-2POSS
your food is spicy indeed

\section{Mirative in Andean Spanish}

In the variety of Spanish spoken in the Andean countries, also known as castellano andino, a mirative interpretation has become associated with some of the compound tenses of the Spanish verbal system. In Peruvian Spanish this role is fulfilled by the pluperfect (pluscuamperfecto). This is illustrated in example (16), which represents an Andean Spanish translation of a Quechuan Mirative. 
$\begin{array}{llllll}\text { (16) así } & \text { había_sido } & \text { la } & \text { voluntad } & \text { del } & \text { Taytacha } \\ \text { like_that } & \text { be.3s.PLUPERFECT } & \text { ART.F } & \text { will } & \text { of.ART.M } & \text { God } \\ \text { that is how God's will turned out to be } & & & \end{array}$

(Escalante and Valderrama 1992: 118)

Since Spanish originally had no mirative tradition, this seems to reflect a clear case of linguistic diffusion from the indigenous Andean languages to the language of the European colonizers in its local variety (cf. de Granda 2002: 103-121; Cerrón-Palomino 2008: 142; Aikhenvald 2004: 297).

In a comparative study of the common structures of the Quechuan and Aymaran languages, Cerrón-Palomino (2008: 142) discusses a 'nonexperienced past', also called 'narrative' or 'mythical' past, which refers to events that do not involve voluntary participation of the subject. He adds that this temporal category, which is considered characteristic for the languages in question, has a second usage, a 'surprise' past, which would have been adopted by Andean Spanish as a local interpretation of the pluscuamperfecto (pluperfect) paradigm. This 'surprise' past coincides with the use of the Quechuan Mirative as attested in Central Peru. It is precisely in the Central Peruvian varieties that the Quechuan Mirative is used today in its most unambiguous form. It is not unlikely that language contact with these varieties at a relatively early stage of the colonization process may have been responsible for the reinterpretation of the pluperfect as a mirative in the Andean variety of Spanish.

\section{Final Consideration: Is the Quechuan Mirative Like Other Miratives?}

As we have seen, the Quechuan Mirative category does not fit the various definitions of mirative that can be found in the literature very neatly. It stands out as an objective and non-emotional type of communication, in which a sensation of surprise has acquired an objective character without necessarily affecting the speaker any longer. As a matter of fact, this is almost never the case in our data. In most examples, the mind of the speaker is no longer unprepared at the moment of speaking. Naturally, surprise and unexpectedness are at the origin of any communication in the Mirative tense, but at the moment of communication itself the element of surprise is more likely to affect the addressee or any other person rather than the speaker him/herself. A contrastive study of the Mirative in different genres, such as story-telling and spontaneous conversation, is a prerequisite for a thorough understanding of the possibilities of the 
Quechuan Mirative. So far, most examples found in the literature belong to the narrative genre, but there are no indications that the interpretation of the Mirative category in interactive contexts would be noticeably different.

The Quechuan Mirative cannot be seen as an extension of the evidential system. Apart from its emergence out of the tense system, the Mirative has few connections with other subsystems of the verb. It is compatible with aspect and two of the three evidentials, and the interaction between it and these categories is minimal. Categories such as the Quechuan Mirative have been found in surrounding languages as well, either as independent categories or as categories derived from other usage, and it seems on its way to becoming an areal feature.

The Mirative in Tarma Quechua shows a high level of grammaticalization, in particular, because it does not have to share its form with other uses, such as Narrative past. This seems reason enough to include the Quechuan-type Mirative in a catalogue of terminology relevant to linguistic typology, when necessary under a different label than the more direct expressions of surprise that have also been referred to as miratives. Possibly, a distinction between the labels 'Mirative' (for the Quechuan type) and 'Surprisive' (for the traditional type) could bring a solution. A more suitable alternative may be to abandon the term 'Mirative' for the Quechuan category at issue and replace it with some more specific denomination such as 'Revelative'.

\section{REFERENCES}

Adelaar, Willem F. H. 1977. Tarma Quechua, Grammar, Texts, Dictionary. Lisse: Peter de Ridder Press.

- 1984. Grammatical vowel length and the classification of Quechua dialects. International Journal of American Linguistics, 50, 1: 25-47.

—. 1986. Morfología del quechua de Pacaraos. Documento 53, Centro de Investigación de Lingüística Aplicada. Lima: Universidad Nacional Mayor de San Marcos.

—. 1988. Categorías de aspecto en el quechua del Perú central (English text). Amerindia 13: $15-41$.

Aikhenvald, Alexandra Y. 2004. Evidentiality. Oxford: Oxford University Press.

Black, Nancy, with Verena Bolli and Eusebio Ticsi Zárate. 1990. Lecciones para el aprendizaje del quechua del sureste de Pasco y el norte de Junín. Cerro de Pasco: Región Andrés Abelino Cáceres, Dirección Departamental de Educación-Pasco \& Instituto Lingüístico de Verano.

Cerrón-Palomino, Rodolfo M. 1976. Gramática quechua Junín-Huanca. Lima: Ministerio de Educación \& Instituto de Estudios Peruanos.

- 1987. Lingüística quechua. Cuzco: Centro de estudios regionales andinos "Bartolomé de las Casas". 
Editores.

Cusihuamán G., Antonio. 1976. Gramática quechua Cuzco-Collao. Lima: Ministerio de Educación \& Instituto de Estudios Peruanos.

DeLancey, Scott. 1997. Mirativity: The grammatical marking of unexpected information. Linguistic Typology 1: 33-52.

- 2001. The mirative and evidentiality. Journal of Pragmatics 33: 369-382.

Escalante, Carmen and Valderrama, Ricardo. 1992. Nosotros los humanos. Ñuqanchik runakuna. Testimonios de los Quechuas del siglo XX. Cuzco: Centro de estudios regionales andinos "Bartolomé de las Casas".

Floyd, Rick. 1999. The Structure of Evidential Categories in Wanka Quechua. Dallas: Summer Institute of Linguistics and the University of Texas at Arlington.

Granda, Germán de. 2002. Lingüística de Contacto: Español y quechua en el área andina suramericana. Valladolid: Universidad de Valladolid.

Hengeveld, Kees and Hella Olbertz. Forthcoming. Didn't you know? Mirativity does exist! (Comment on a paper by Nathan W. Hill: 'Mirativity' does not exist: hdug in 'Lhasa' Tibetan and other suspects.)

Hintz, Diane M. 2007. Past tense forms and their functions in South Conchucos Quechua: Time, evidentiality, discourse structure, and affect. PhD thesis, University of California at Santa Barbara.

- 2011. Crossing Aspectual Frontiers. Emergence, Evolution, and Interwoven Semantic Domains in South Conchucos Quechua Discourse. University of California Publications in Linguistics, Volume 146. Berkeley and Los Angeles: University of California Press.

Howard-Malverde, Rosaleen. 1988. Talking about the past: Tense and testimonials in Quechua narrative discourse. Amerindia 13: 125-155.

Olbertz, Hella. 2009. Mirativity and Exclamatives in Functional Discourse Grammar: Evidence from Spanish. In: Evelien Keizer and Gerry Wanders (eds). The London Papers I, Special Issue of Web Papers in Functional Grammar 82: 66-82.

Parker, Gary J. 1976. Gramática quechua Ancash-Huailas. Lima: Ministerio de Educación \& Instituto de Estudios Peruanos.

Torero, Alfredo A. 1964. Los dialectos quechuas. Anales Científicos de la Universidad Agraria 2, 4: 446-478. La Molina, Lima.

Vienrich, Adolfo. 1961 [1905]. Azucenas quechuas. Tarma: Ediciones Lux.

Weber, David J. 1989. A Grammar of Huallaga (Huánuco) Quechua. University of California Publications in Linguistics, Volume 112. Berkeley and Los Angeles: University of California Press.

Wroughton, John R. 1996. Gramática y textos del quechua Shausha Huanca. Pucallpa: Ministerio de Educación \& Instituto Lingüístico de Verano. 
